\title{
Groundwater development in a mixed geological terrain: a case study of Niger State, central Nigeria
}

\author{
A. Idris-Nda ${ }^{1}$, S. I. Abubakar ${ }^{2}$, S. H. Waziri ${ }^{1}$, \\ M. I. Dadi \& A. M. Jimada ${ }^{2}$ \\ ${ }^{1}$ Department of Geology, Federal University of Technology, Nigeria \\ ${ }^{2}$ Niger State RUWATSAN Agency, Nigeria
}

\begin{abstract}
Groundwater occurrence and characteristics of Niger State, Nigeria was studied using a combination of geological, hydrogeological and geophysical survey methods. Geological studies involved a determination of the various rock types and lithology, hydrogeological investigations involved the use of water levels in open hand dug wells and boreholes, while geophysical survey methods involved the use of electrical resistivity methods to determine subsurface conditions. The state is basically underlain by crystalline and the sedimentary rocks occurring in equal proportion. The crystalline rocks comprises mainly of granite, gneisses, migmatite and schist while the sedimentary deposits are mostly made up of sandstone, clays and shale. Groundwater occurs in the area in three broad categories; fractured/weathered aquifers in hard rock terrain, sandstone/grit aquifer in the sedimentary rock terrain and sandstone/conglomerate/ fractured rock in geologic contact areas. Groundwater yield varies widely in the three categories. Shallow sedimentary aquifers have the highest yield of about 1.4-2.8 lt/s (120 $\left.241 \mathrm{~m}^{3} / \mathrm{d}\right)$, granite/gneiss/migmatite have a yield of $0.8-1.8 \mathrm{lt} / \mathrm{s}\left(70-155 \mathrm{~m}^{3} / \mathrm{d}\right)$ groundwater in the schist is low (below $0.6 \mathrm{lt} / \mathrm{s}$ ) and sometimes wells placed in them are non-productive. Groundwater yields in the geologic contact areas vary from very low, where non fractured rock is overlain by clay, while very high yield is obtained in areas where the contact point is represented by conglomerate. Groundwater development in the state can best be achieved through a combination of geological, hydrogeological and geophysical survey methods.
\end{abstract}

Keywords: aquifer, basement complex, sedimentary basin, groundwater yield, wells, boreholes, Niger State, geology, fractured, weathered. 


\section{Introduction}

Searching for groundwater is a hydrogeological inference task that incorporates a detailed study of the geology and hydrogeological conditions of the area, and also the use of indirect surface geophysical methods, though much emphasis has been placed recently on geophysical survey alone, chiefly the electrical resistivity method. The general pattern of groundwater occurrence is dependent upon the physical framework in which groundwater occurs and the hydrologic balance that results from recharge and discharge mechanisms. The local occurrence of groundwater is the consequence of a finite combination of climatic, hydrologic, geologic, topographic and soil forming factors which together form an integrated dynamic system. Understanding these mechanisms will go a long way in ensuring that groundwater is developed optimally for use, costly failure rates reduced and protected from contamination and excessive withdrawal.

\section{Geographical and geological setting}

Niger State lies between latitudes $8^{\circ} 15^{\prime}-11^{\circ} 15^{\prime} \mathrm{N}$ and longitudes $4^{\circ} 00-7^{\circ} 15^{\prime} \mathrm{E}$. It is bordered in the north by Kaduna and Kebbi states and in the south by Kogi state. It shares boundary in the west with Kwara state and Benin Republic and in the east with the Federal Capital Territory and Kaduna state. It is divided into twenty five local governments with a landmass of about $80,000.00$ square kilometers and a population of 3,920,000 (2006 census). The climate is like much of West Africa comprising of a rainy season and a dry season. The seasonal rainfall regime gives rise to a longer wet season of about seven months with an average rainfall of 250 $\mathrm{mm}$, and a dry season of about five months with little or no rains at all. About one half of the land mass of Niger State is underlain by the basement complex rocks while the other is occupied by the Cretaceous sedimentary rocks of the Bida Basin and part of the Sokoto (Iullemeden Basin). Figure 1 is the geological map of Nigeria showing Niger State modified after Obaje [1].

The basement rocks consist of a suite of Precambrian gneisses, migmatites and metasedimentary schists crosscut by granitoids [2-4]. The migmatite-gneiss complex includes migmatites, gneisses, mylonites and amphibolites. The mylonites are major shear zones which mark the stratigraphic breaks between the gneissic basement complex and the cover rocks of the Birnin-Gwari Schist formation [5]. Figure 2 is the generalized geological map of Niger State showing the major lithological units.

The schist belts area occur as two elongated bodies separated by the older granite suite. The tips of the two formations are separated by a $40 \mathrm{~km}$ expanse of the older granite suite [6]. However this study indicates a much smaller separation of less than $10 \mathrm{~km}$. The Birnin-Gwari formation lies to the west of the older granite (the Minna Batholith) while the Kushaka formation lies to the East. A gravity survey model conducted over the area showed that the two formations have a maximum thickness of 11 and $6 \mathrm{~km}$ respectively. 


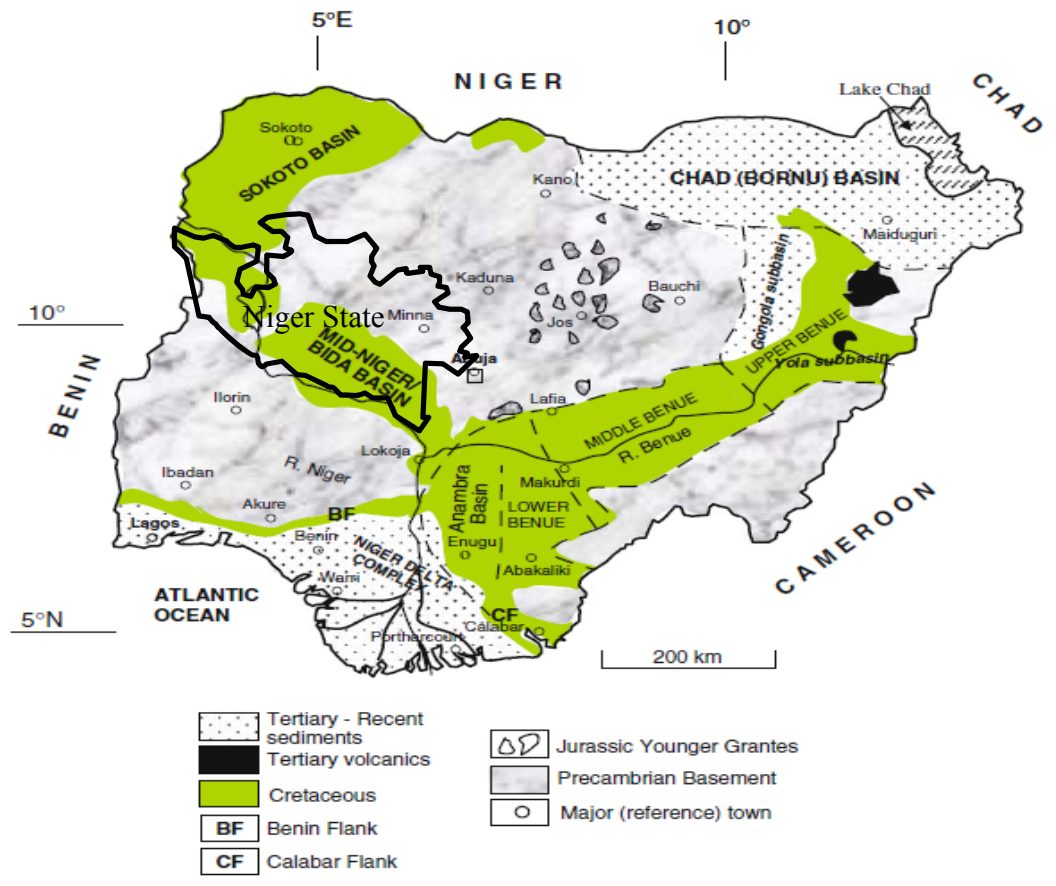

Figure 1: Geological map of Nigeria showing Niger State [1].

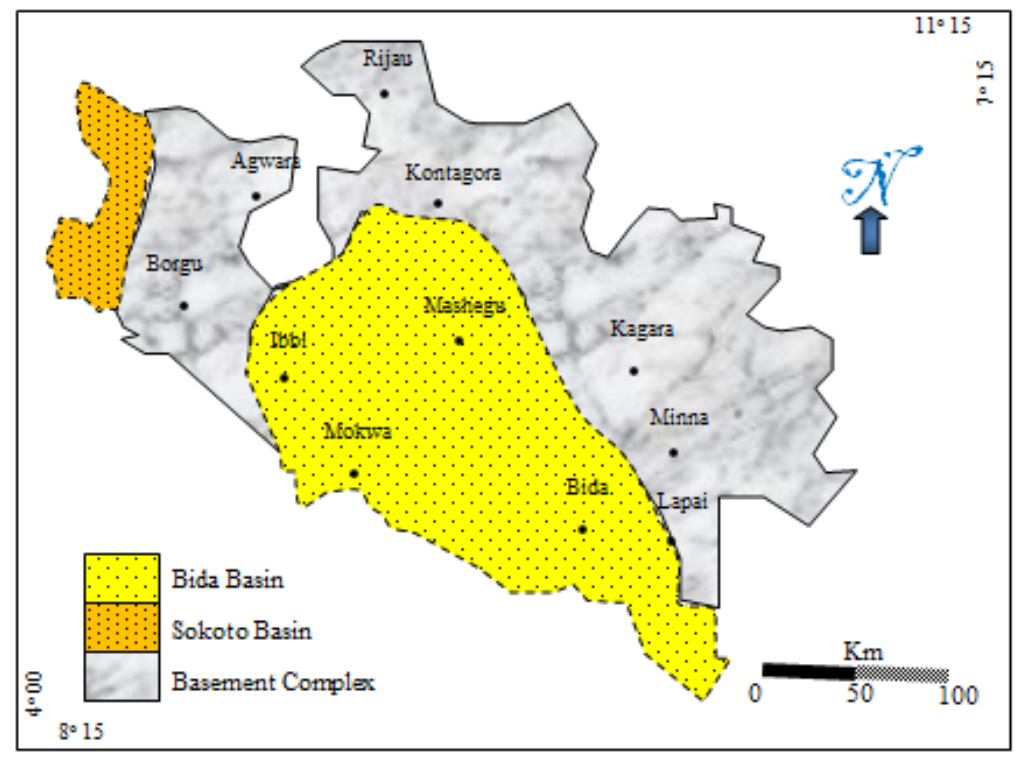

Figure 2: Generalised geological map of Niger State. 
The sedimentary formations belong to the Bida Basin of deposition, the Bida Basin otherwise known as the mid-Niger Basin or the Nupe Basin is a NW-SE trending intracratonic sedimentary basin extending from Kontagora in Niger State to areas slightly beyond Lokoja in the south. Its total length is estimated at $400 \mathrm{~km}$ with a maximum width of about $160 \mathrm{~km}$ which tapers to less than $60 \mathrm{~km}$ at Dekina. The largest portion of the basin (the northern part), occurs in the southern half of Niger State.

\section{Statement of the problem}

The use of groundwater as the major source of potable water in both urban and rural areas in Niger State has assumed such a high proportion that attention has turned fully to it. Against the backdrop of poor, erratic and unreliable public water by the state government, over $80 \%$ of the population depend on groundwater as the main source of potable water for drinking and other domestic purposes as well as for packaging in sealed polythene bags for sale and even for agriculture. Groundwater development in Niger State has met with high success rate in some places, limited success in some other places and outright failure in others, despite a seemingly successful geophysical survey. Groundwater exploitation in Niger State is mainly through hand-dug wells and boreholes. The wells are commonly lined or unlined serving both individual households and community water points. Boreholes have become the most common used source of water in the state. An average of over three thousand (3000) boreholes has been drilled in the state. The depths of the boreholes range between $30-200 \mathrm{~m}$ with an average of $50 \mathrm{~m}$. As a result of rapid decline in shallow sources of water in the basement areas, greater emphasis is now laid on deeper boreholes targeting deeply seated fractures.

This work is therefore aimed at determining the reason (s) responsible for high groundwater potential (yield) in some places and low in others and to propose the best method or combination of methods most suitable for groundwater development in Niger State.

\section{Methodology}

Challenges of groundwater development in Niger State was studied using a combination of Geology, Hydrogeology and Geophysical survey methods. These were used in addition to other secondary data obtained from all relevant Ministries, Departments and Agencies as well as those from donor agencies like United Nations Children Fund (UNICEF), Japanese International Cooperation Agency (JICA) and European Economic Community (EEC)/Middle Belt Programme, the first two operated through the Niger State Rural Water Supply and Sanitation Agency (RUWATSAN), while the EEC/Middle Belt programme operated in the state between 1996 and 2000. 


\subsection{Geology}

The geology of Niger State was studied using information from earlier workers in the area like Truswell and Cope [5], Ajibade et al. [6]. Further geological information was obtained from fieldwork carried out in the area over the years by staff and students of Geology Department, Federal University of Technology, Minna. For the purpose of this study geological mapping of some areas in the state, notably the geological contact areas was done by the authors on a scale of $1: 100,000$. These studies were used to correct the geological boundaries and also to redefine some of the lithology.

\subsection{Hydrogeology}

Hydrogeological investigations carried out include water level measurements in wells and boreholes, borehole logs observed from drilling of boreholes, geophysical wireline logs in boreholes, pumping tests, and particle size distributions (sieve analysis) of geological materials. Hydrogeological investigations, including actual supervision and logging of boreholes and sampling of soil and water for analysis, was conducted by the authors in both dry and rainy seasons. Water level elevation maps were drawn by using the difference between the elevation and water level, these were then plotted using Surfer 11 contouring software.

\subsection{Geophysics}

The subsurface data of interest in this study using surface geophysical surveys include the following:

1. Depth to aquifer

2. Thickness of aquifer

3. Horizontal changes in aquifer

4. Geological boundaries

These parameters were determined using the electrical resistivity method of surveys, and the electrode configurations deployed for the study were the Schlumberger and modified Schlumberger arrays.

\section{Results and discussions}

Table 1 shows the results of water levels in selected parts of the state, it represents water levels in the basement, sedimentary and contact areas.

Figures 3 to 5 are the contour plots and digital elevation models of water levels across Niger State, deeper water levels occur mostly in the sedimentary areas while shallow levels are noticed mostly in areas along Rivers Niger and Kaduna, mostly in the flood plains. The basement rock areas have varied water levels which is a direct reflection of the depth and degree of weathering. Highest water in hard rock areas is $20 \mathrm{~m}$ and this occurs around the southern part of the state. The geology of this area is represented by Kushaka Schist, the other areas are contact areas like 
Kontagora and Lapai. In these areas the transition from basement to sedimentary rock areas is less than $500 \mathrm{~m}$. Wells and boreholes in these areas are very deep and poor, yielding sometimes less than $0.41 / \mathrm{s}\left(35 \mathrm{~m}^{3 /} / \mathrm{d}\right)$.

Table 1: Depth of wells and water levels in Niger State.

\begin{tabular}{|c|c|c|c|c|c|c|}
\hline \multirow[t]{2}{*}{ S/No } & \multirow[t]{2}{*}{ Location } & \multicolumn{2}{|c|}{ Coordinate } & \multirow{2}{*}{$\begin{array}{c}\text { Elev } \\
\mathbf{m}\end{array}$} & \multirow[t]{2}{*}{ Terrain } & \multirow{2}{*}{$\begin{array}{c}\begin{array}{c}\text { Water } \\
\text { Level }\end{array} \\
\mathbf{m} \\
\end{array}$} \\
\hline & & $\mathbf{N}$ & $\mathbf{E}$ & & & \\
\hline 1 & Minna & 9.36 & 6.33 & 253 & Basement & 10 \\
\hline 2 & Paiko & 9.26 & 6.38 & 320 & Basement & 10 \\
\hline 3 & Lambata & 9.26 & 6.51 & 339 & Basement & 4 \\
\hline 4 & Suleja & 9.12 & 7.10 & 443 & Basement & 8 \\
\hline 5 & Ijah & 9.13 & 7.12 & 487 & Basement & 12 \\
\hline 6 & Sabon Wuse & 9.14 & 7.16 & 486 & Basement & 10 \\
\hline 7 & Adunu & 9.32 & 7.06 & 536 & Basement & 6 \\
\hline 8 & Kafin Koro & 9.31 & 7.05 & 513 & Basement & 6 \\
\hline 9 & Kuta & 9.52 & 6.42 & 308 & Basement & 6 \\
\hline 10 & Sarikin Pawa & 10.01 & 7.06 & 411 & Basement & 6 \\
\hline 11 & Galadiman Kogo & 10.05 & 6.53 & 401 & Basement & 3 \\
\hline 12 & Kontagora & 10.24 & 5.28 & 348 & Contact & 12 \\
\hline 13 & Lapai & 9.02 & 6.34 & 161 & Contact & 6 \\
\hline 14 & Auna & 10.11 & 4.43 & 184 & Contact & 3 \\
\hline 15 & Salka & 10.18 & 4.58 & 290 & Contact & 8 \\
\hline 16 & Labozhi & 9.11 & 5.25 & 110 & Sedimentary & 9 \\
\hline 17 & Kudu & 9.16 & 5.21 & 167 & Sedimentary & 5 \\
\hline 18 & Mokwa & 9.19 & 5.09 & 158 & Sedimentary & 40 \\
\hline 19 & Muregi & 8.45 & 5.47 & 55 & Sedimentary & 2 \\
\hline 20 & Nupeko & 8.47 & 5.46 & 61 & Sedimentary & 2 \\
\hline 21 & Bida & 9.05 & 5.39 & 147 & Sedimentary & 12 \\
\hline 22 & Ibbi & 9.4 & 4.55 & 186 & Sedimentary & 32 \\
\hline 23 & Mashegu & 9.55 & 5.39 & 251 & Sedimentary & 42 \\
\hline 24 & Matane & 10.01 & 5.38 & 254 & Sedimentary & 27 \\
\hline 25 & Bokani & 9.26 & 5.13 & 172 & Sedimentary & 22 \\
\hline 26 & Makeri & 9.41 & 5.24 & 231 & Sedimentary & 24 \\
\hline 27 & Kaboji & 10.06 & 5.24 & 280 & Sedimentary & 32 \\
\hline 28 & Kontagora & 10.24 & 5.27 & 361 & Sedimentary & 25 \\
\hline 29 & Tunga wawa & 10.2 & 5.24 & 342 & Sedimentary & 24 \\
\hline 30 & Edati Eshata & 9.12 & 5.65 & 266 & Sedimentary & 39 \\
\hline 31 & Chegungi & 9.12 & 5.69 & 275 & Sedimentary & 40 \\
\hline 32 & Sidi Saba & 8.96 & 6.14 & 140 & Sedimentary & 20 \\
\hline 33 & Jima & 9.02 & 5.52 & 205 & Sedimentary & 15 \\
\hline 34 & Dokota & 9.12 & 5.96 & 184 & Sedimentary & 16 \\
\hline 35 & Emi Ndaisah & 9.13 & 5.65 & 277 & Sedimentary & 41 \\
\hline 36 & Gbedako & 8.61 & 6.64 & 188 & Sedimentary & 39 \\
\hline
\end{tabular}




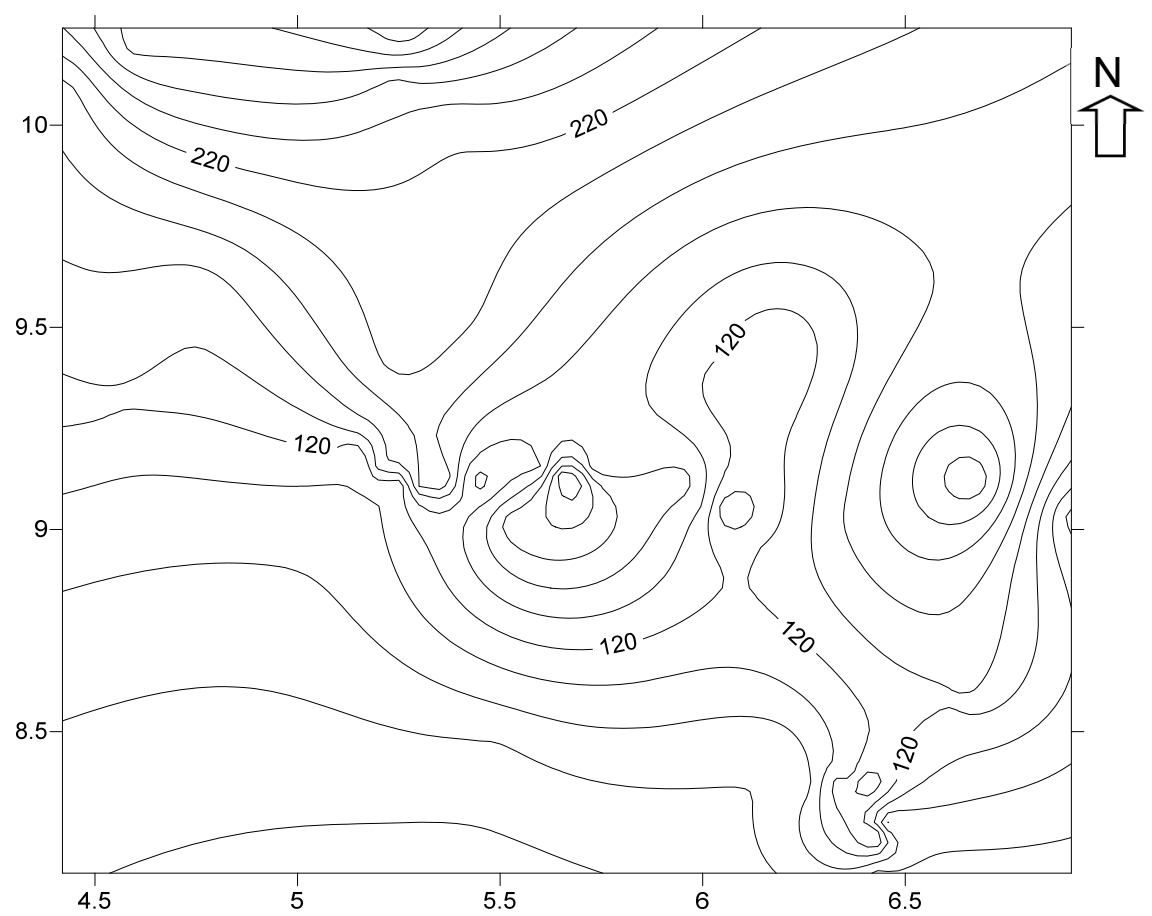

(a)

Water level elevation $(\mathrm{m})$

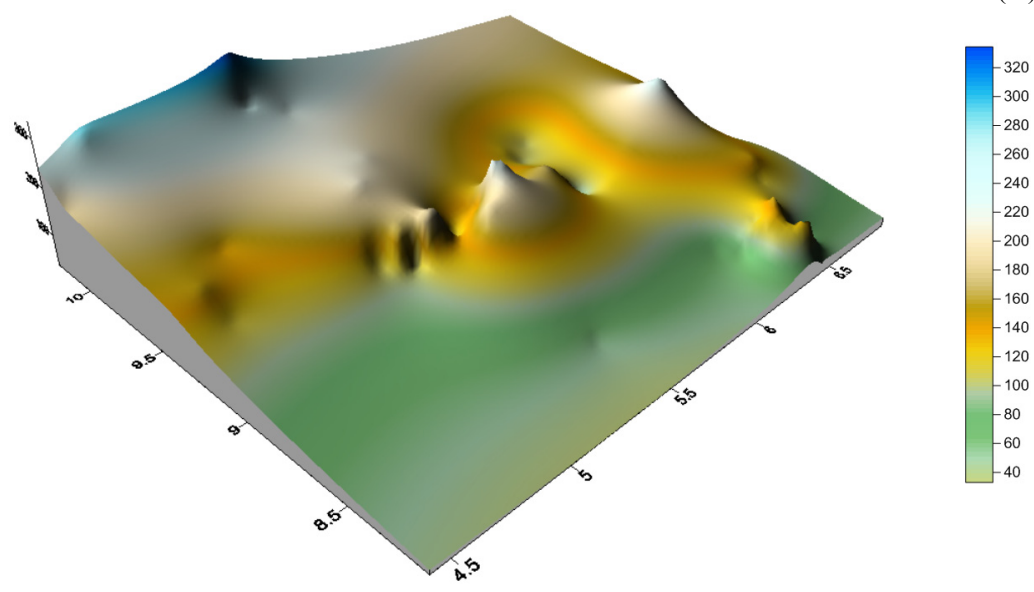

(b)

Figure 3: Water level elevation map (a) and digital elevation model (b) in basement areas. 


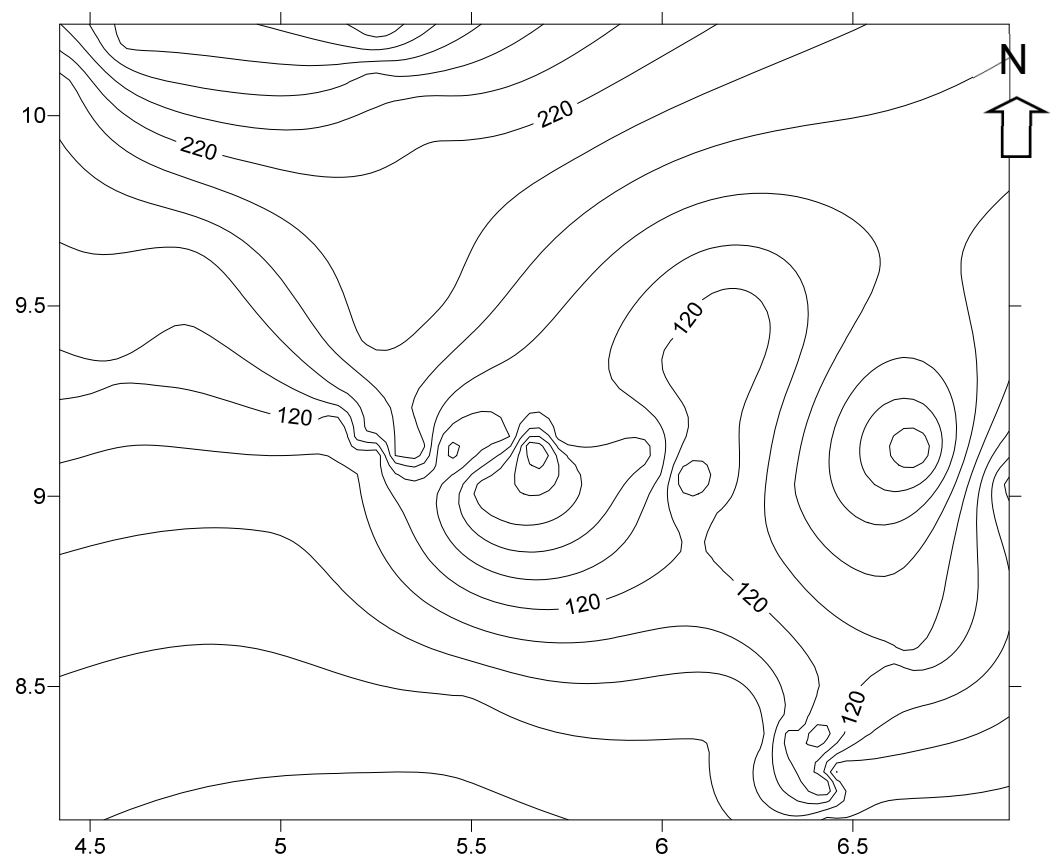

(a)

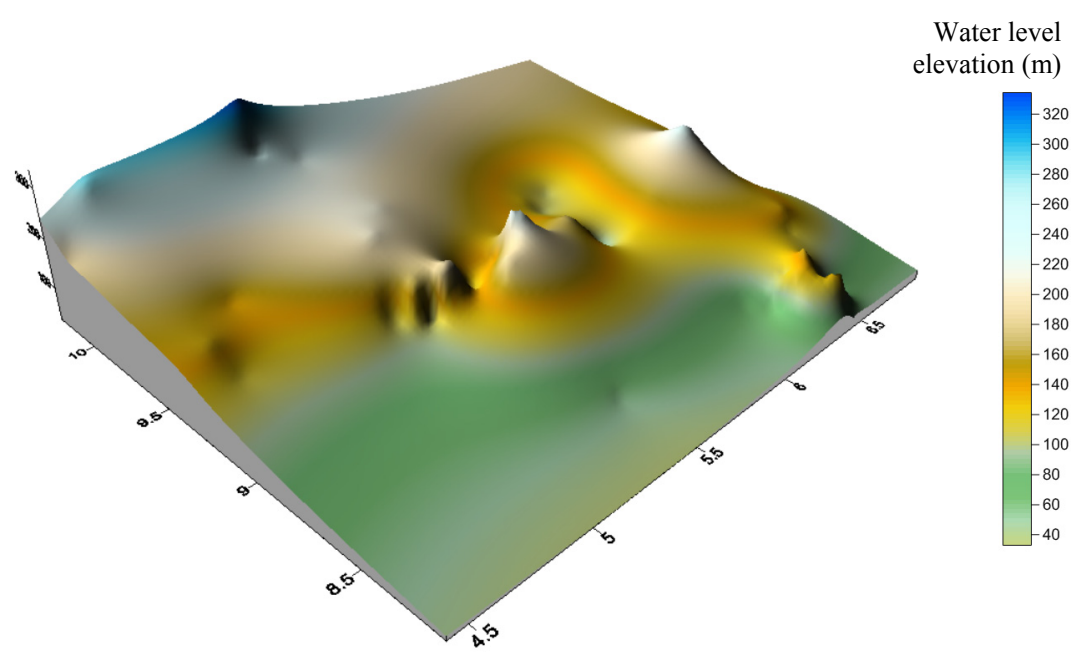

(b)

Figure 4: Water level elevation map (a) and digital elevation model (b) in sedimentary areas. 


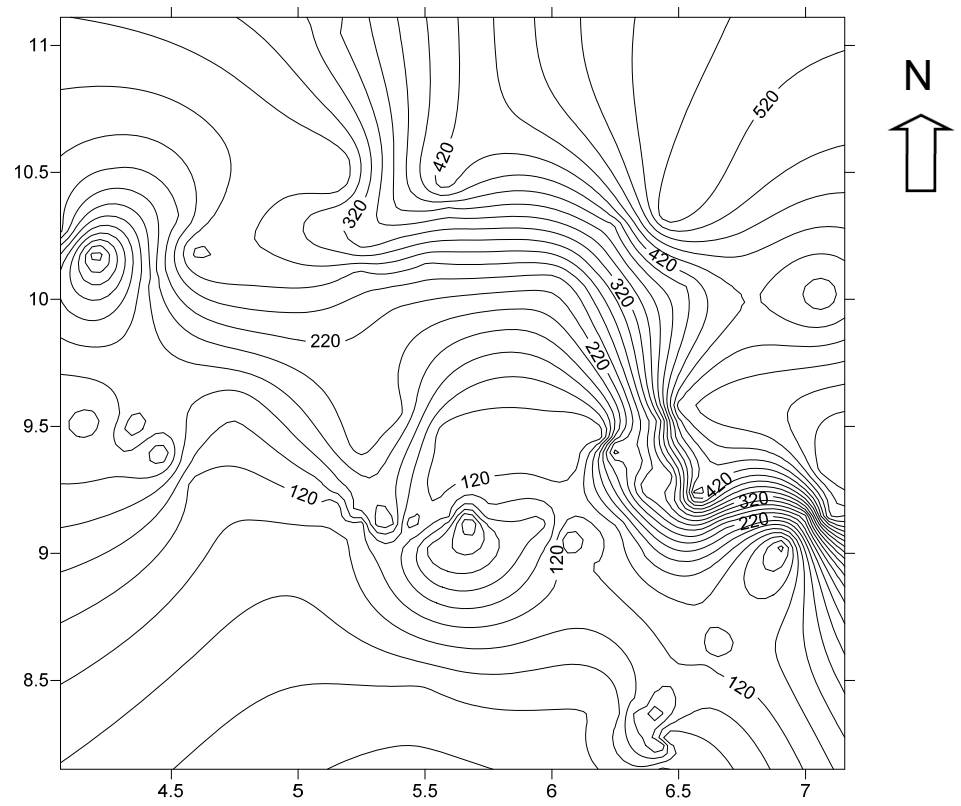

(a)

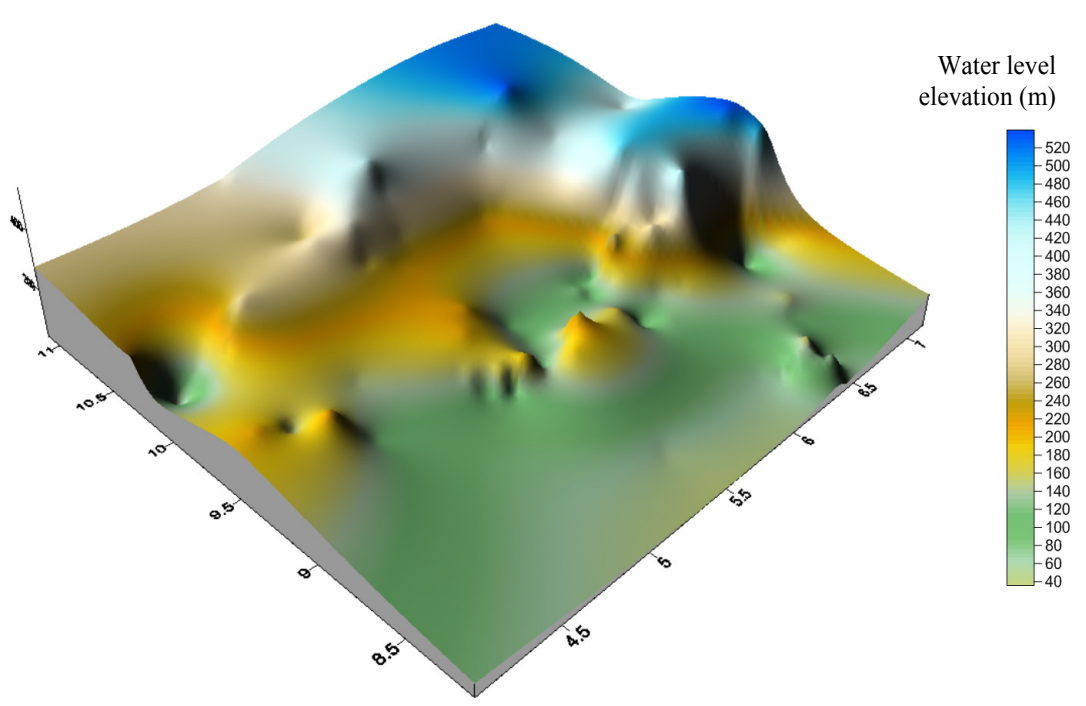

(b)

Figure 5: Generalised water level elevation map (a) and digital elevation model (b) in Niger State. 
Figure 6 is the aquifer geometry for Bida which is at the central part of the sedimentary basin and Lapai which is at the fringes and is mostly on the basement complex. Figure 7 is a map of the state showing areas with low groundwater potential (coloured red), well depths in these areas are in excess of $100 \mathrm{~m}$.

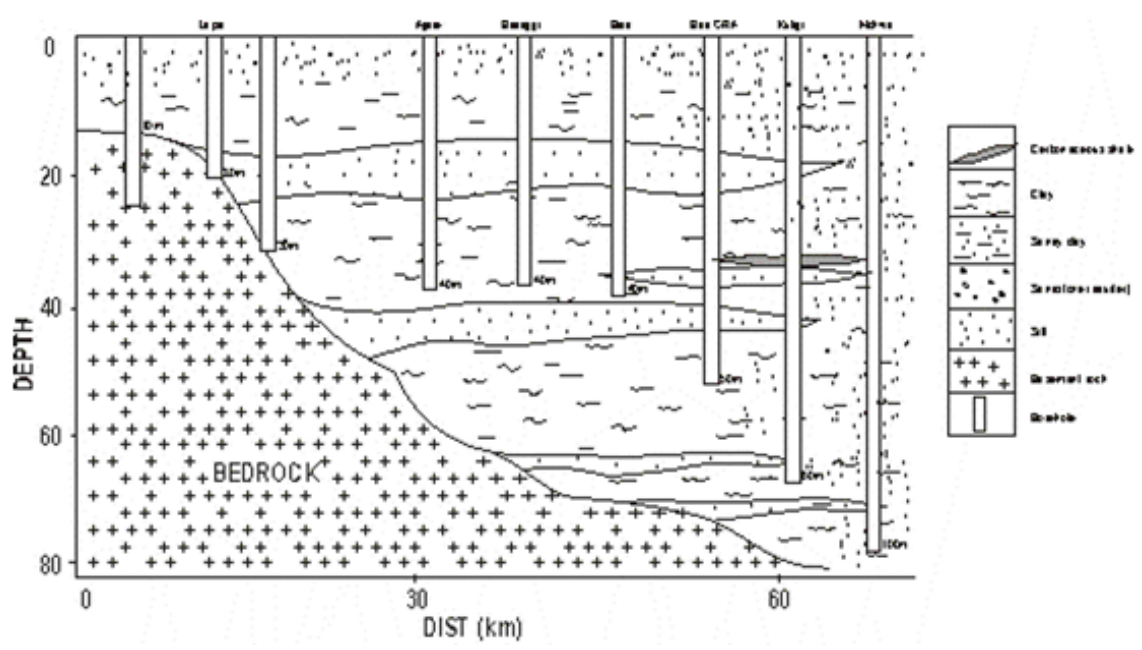

Figure 6: Aquifer geometry in Bida and Lapai areas as determine from borehole logs.

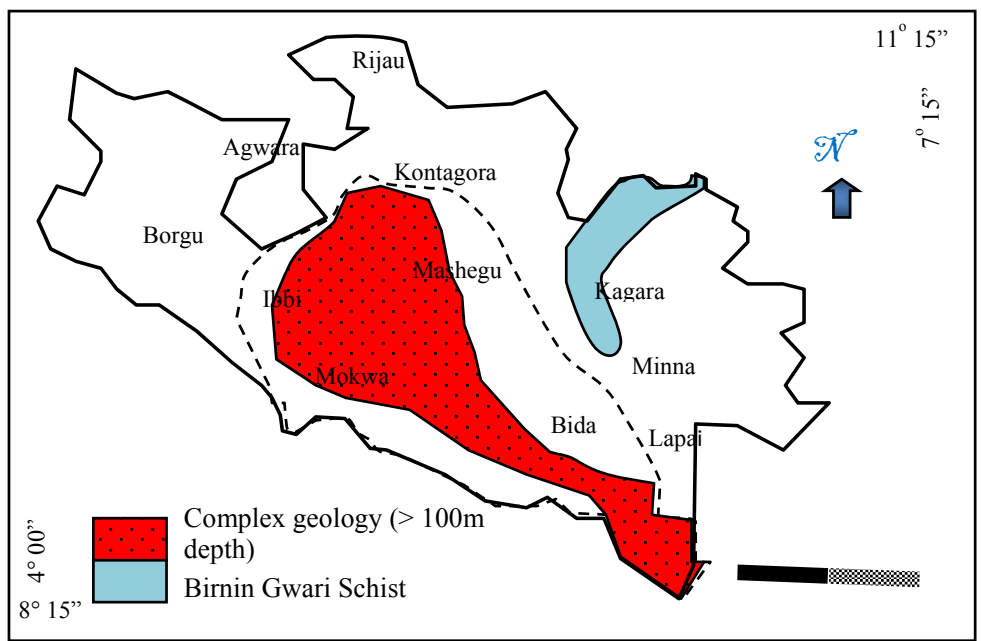

Figure 7: Areas with low groundwater potential in Niger State. 


\section{Conclusion}

Groundwater occurrence in Niger State is controlled by the prevailing climatic factors and geology. Areas underlain by the basement complex rocks have greater groundwater potential when deeply weathered or fractured. Depth and intensity of weathering varies widely in the area and range from $2 \mathrm{~m}$ to $30 \mathrm{~m}$, the weathered product mostly comprises of sand and clay with the former having a higher percentage. Fracture density is low with most fracture sets ranging from two to three and even in some cases only one. The fractures range in depth from $25 \mathrm{~m}$ to $130 \mathrm{~m}$. Poor groundwater yields are obtained in areas underlain by the Birnin Gwari schist, this area is quite extensive. Groundwater occurrence in areas underlain by the Bida basin is also variable, water level ranges from $5 \mathrm{~m}$ to 100 $\mathrm{m}$. Shallow levels occur around the fringes of the basin and gets progressively deeper towards the center. Towards the southern part of the basin the geology is predominantly sand, clay and shale, the thick shale unit result in deep water levels in the area. Geophysical surveys, especially the commonly used resistivity surveys, is a useful tool in determining suitable points for groundwater development in the area, however it must be used in conjunction with the geology and hydrogeology of the area for optimal results.

\section{References}

[1] Obaje, N. G., (2009) Geology and Mineral Resources of Nigeria, Lecture Notes in Earth Sciences 120, DOI 10.1007/978-3-540-92685-6 1, C SpringerVerlag Berlin Heidelberg, 2009.

[2] Oyawoye, M.O. 1972. The Basement Complex of Nigeria. In Dessauvagie and Whiteman, A.J. (Eds.). African Geology. Ibadan University Press, pp. 6798.

[3] McCurry, P. 1989. A general review of the geology of the Precambrian to Lower Paleozoic rocks of northern Nigeria. In Kogbe, C.A. (Ed.). Geology of Nigeria, 2nd Edition. Rock View (Nigeria) Ltd, Jos, pp. 13-37.

[4] Ajibade, A.C., Woakes, M. and Rahaman, M.A. 1989. Proterozoic Crustal development in the pan-African Regime of Nigeria. In Kogbe, C.A. (Ed.). Geology of Nigeria, 2nd Edition. Rock View (Nigeria) Ltd, Jos, pp. 57-69.

[5] Truswell, J.F., Cope, R.N. 1963. The geology of parts of Niger and Zaria Provinces, Northern Nigeria. Geol Survey Nigeria Bull 29, 1-104.

[6] Ajibade, A.C., Anyanwu, N.P.C., Okoro, A.U. and Nwajide, C.S. 2008. The Geology of Minna Area: Explanation of 1:250,000 Sheet 42 (Minna). Nigeria Geological Survey agency Bull. No 43, p. 112. 